Available online on 15.04.2020 at http://jddtonline.info
Open Access to Pharmaceutical and Medical Research
unrestricted non-commercial use, provided the original work is properly cited

Open@Access

Research Article

\title{
Synthesis and Biological Evaluation of Benzimidazoles as Target for $\alpha$ - Glucosidase Inhibitors
}

\author{
Shweta Mishra*, Rashmi Dahima, Rajesh Sharma \\ School of Pharmacy, Devi Ahilya Vishwavidyalaya, Takshashila Campus, Khandwa Road, Indore-452001, M.P., India
}

\begin{abstract}
Diabetes mellitus is rising globally touching more than 180 million people worldwide. This is prevailing mostly in type 2 diabetes and according to WHO report the incidence is likely to be more than doubled by 2030. $\alpha$-glucosidase inhibitors work by reducing the amount of glucose that the intestines absorb from food. In our previous work, forty-five benzimidazoles analogues were studied using 3D QSAR, HQSAR, and Pharmacophore mapping and based on their results 60 compounds were designed. Docking studies of those designed compounds showed that most of the compounds are bonding with important amino acids LEU 520, ARG 335 and ASP 69 through hydrogen bonds and steric in teraction. In this work, synthesis of eleven compounds was done on the basis of molecular docking studies. Compounds containing hydroxyl and alkyl groups (compound no. 3, 9 and 10) were found to be five to eight folds more active with IC 90 values in the range of $6.02 \pm 1.10$ to $33.25 \pm 1.20$ $\mu \mathrm{g} / \mathrm{ml}$, in comparison with the standard drug, Acarbose ( $\mathrm{IC}_{90}=290.55 \pm 0.081 \mu \mathrm{g} / \mathrm{ml}$ ). Thus, these compounds after the toxicity studies could be of therapeutic use in treating diabetes.
\end{abstract}

Keywords: Acarbose, Alpha-glucosidase inhibition, Benzimidazoles, Docking, Molecular modelling, Post-prandial hyperglycemia

Article Info: Received 29 Jan 2020; Review Completed 26 March 2020; Accepted 31 March 2020; Available online 15 April 2020

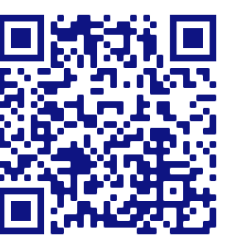

Cite this article as:

Mishra S, Dahima R, Sharma R, Synthesis and Biological Evaluation of Benzimidazoles as Target for $\alpha$-Glucosidase Inhibitors, Journal of Drug Delivery and Therapeutics. 2020; 10(2-s):43-49 http://dx.doi.org/10.22270/jddt.v10i2-s.4019

*Address for Correspondence:

Shweta Mishra, Doctoral Research Fellow, School of Pharmacy, Devi Ahilya Vishwavidyalaya, Takshashila Campus, Khandwa Road, Indore-452001, M.P., India.

\section{INTRODUCTION}

Diabetes mellitus is a persistent metabolic disorder diagnosed by hyperglycemia, glycosuria, hyperlipidemia, negative nitrogen balance and sometimes ketonaemia. Over 18 years of age the international occurrence of diabetes among adults has ascended from $4.7 \%$ in 1980 to $8.5 \%$ in 2014 (Global report on diabetes. WHO, Geneva, 2016). In 2030 diabetes would be the seventh leading cause of death as per the World Health Organization (WHO) (Mathers CD, Loncar D, 2006). The effects of diabetes mellitus include long term damage, dysfunction and of various organs. Adult-onset blindness, lower limb amputations and kidney failure are the major outcomes of diabetes (Alberti K, Zimmet Z.1999).

A common and severe difficulty confronted by many people with type 2 diabetes is postprandial hyperglycemia, $\alpha$ glucosidase inhibitors (AGIs) are well suited for its treatment (Vats Rajesh.2005). Furthermore, $\alpha$-glucosidase may also be used as therapeutic target for other carbohydrate mediated diseases including cancer, HIV and hepatitis. Alpha-glucosidase is located in the brush border of the small intestine that acts upon 1, 4- alpha bonds. Most of the carbohydrates are present as oligo- or poly- saccharides, and have to be broken down to disaccharides, before sucrose, isomaltase, maltase, glycol-amylase, and lactase break them into digestible mono-saccharides (Kalra S., 2014). AGIs inhibits both alpha amylase and the other $\alpha$ glucosidases, thus preventing absorption of starch and other carbohydrates from the brush border of the intestine.

Benzo-hydrazides had been reported to possess various biological activities, which includes anti-leishmanial (Taha et al., 2014b), anti-oxidant (Aziz et al., 2014, Khan et al., 2012), anti-glycation (Khan et al., 2013a, Khan et al., 2013b, Khan et al., 2015, Jamil et al., 2015), antibacterial (Imran et al., 2014), and $\alpha$-glucosidase inhibition (Taha et al., 2015f) activities. Benz-imidazole nucleus is an important pharmacophore with unique chemical and biological properties. Benzimidazoles have been found to possess anti-inflammatory (Kohno T, et. al. 1990), antidiabetic (Bhise UN, et. al. 2008), antispasmodic (Francisco AC, et. al. 2006), diuretics (Pashinski VG, et. al. 1978), analgesic (Kohno T, et. al. 1990), antimicrobial (Durmaz R, et. al. 2003), anti-helminthic (Solominova PS, et. al. 2004), anti-HIV (Gardiner JM, et. al. 1995), antiulcer (Bariwal JB, 2008), anticancer (Gellis A, et. al. 2008), and anticonvulsant activities (Chimrri A, et al. 2001).

Furthermore, recent studies have shown that some benzimidazole derivatives have been identified to exhibit $\alpha$ glucosidase inhibitory activity. In our work, we have 
combined benzohydrazide and benz-imidazole nucleus, and developed SAR based on 3D-QSAR, HQSAR studies and Pharmacophore Mapping. Further from docking results, 11 compounds were synthesized based on their dock scores. The synthesized compounds were tested for their in vitro $\alpha$ glucosidase inhibitory activity.

\section{EXPERIMENTAL}

\section{Chemistry}

Melting points were determined by Veego model VMP-D melting point apparatus and were uncorrected. Thin layer chromatography was performed on precoated silica gel-G ( $0.2 \mathrm{~mm}$ thick) using different solvent system (petroleum ether: acetone 7:3, n-hexane: ethyl acetate 5:5) to ascertain the purity of the synthesized compounds. UV light and iodine vapors were used as the detecting agents. Infrared spectrum was taken on FT-IR-SP 10 STD at School of Chemical Sciences, Devi Ahilya Vishwavidyalaya, Indore. ${ }^{1} \mathrm{H}-\mathrm{NMR}$ and ${ }^{13} \mathrm{C}$-NMR spectrums were obtained on Bruker DRX-400 (400 MHz FT-NMR) at sophisticated analytical instrument facility, Panjab University, Chandigarh. Mass spectrum were obtained on Water UPLC-TQD (electron ionization spray and ACPI-MS) at sophisticated analytical instrument facility, CDRI, Lucknow.

\section{General Procedure for the Synthesis of Compounds 1-11}

Initially 0.001 moles of o-phenylenediamine (for first five compounds) and 2, 3-diamino naphthalene (for next six compounds) was taken into a round bottom flask and to it methyl-4-formyl benzoate ( 0.001 moles) was added. Ceric ammonium nitrate and hydrogen peroxide in catalytic amount was carefully added to the above mixture. This mixture was carefully assembled over heating mantle maintained at $50{ }^{\circ} \mathrm{C}$. The TLC was taken at the regular interval and it is observed that the completion of reaction took $60 \mathrm{~min}$. The reaction mixture was allowed to dry at room temperature. This intermediate product (IM 1) was taken into next step.

The intermediate was purified and 0.001 mole was taken in a round bottom flask, hydrazine hydrate $(10 \mathrm{ml}, 95 \%)$ was added to it along with $25 \mathrm{ml}$ of ethanol and magnetically stirred for $9 \mathrm{~h}$ maintaining a temperature of $120{ }^{\circ} \mathrm{C}$. the completion of reaction is confirmed by TLC. This reaction mixture was allowed to cool at room temperature, to this mixture ice cold water added and filtered. The intermediate formed was collected on Whatmann filter paper, which was further purified and crystallized using n-hexane and methanol. This intermediate (IM 2) was then taken into next step.

To this intermediate different benzaldehydes were added (equimolar) into round bottom flask and to this mixture, glacial acetic acid in catalytic amount was added and to this mixture 1-butanol $(25 \mathrm{ml})$ was added. This mixture was again refluxed for $3 \mathrm{~h}$. The completion of reaction was confirmed by TLC. The obtained mixture was allowed to cool at room temperature; ice cold water was added to the mixture and the obtained product was filtered using Whatmann filter paper and collected product was dried, recrystallized and purified by using n-hexane and ethanol. The obtained product was allowed to air dry (Panda et. al. 2016, Taha et al. 2015, Rostamizadeh S et al.2009, Kiumars Bahrami.2008).

(E)-N'-(4-diethylamino) benzlidene)-4-(1H-benzo[d] imidazol-2-yl)benzohydrazide

Yield 97.83\%; M.P. $275-276{ }^{\circ} \mathrm{C}$; FTIR (KBr) 3422 (NH of hydrazide), 3197 (NH of imidazole), 1680 (C=0), 1591, 1567
(NH bend.), 1354, 1311, 1291 (C-N), 1073 (N-N), 861, 835 (p-disubstituted rings); ${ }^{1} \mathrm{H}-\mathrm{NMR}(400 \mathrm{MHz}, \mathrm{DMSO}) \delta \mathrm{ppm}: \delta$ $11.6 \mathrm{ppm}(\mathrm{s}, 1 \mathrm{H}, \mathrm{NH}), \delta 8.34 \mathrm{ppm}(\mathrm{s}, 1 \mathrm{H}, \mathrm{CH}=\mathrm{N}), \delta 6.68-8.32$ $(\mathrm{m}, 13 \mathrm{H}, \mathrm{Ar}-\mathrm{H}), \delta 1.0-1.11\left(\mathrm{~m}, 6 \mathrm{H}, \mathrm{CH}_{3}\right), \delta 3.33-3.38(\mathrm{~m}, 4 \mathrm{H}$, $\left.\mathrm{CH}_{2}\right) ;{ }^{13} \mathrm{C}-\mathrm{NMR} \delta 161.97(\mathrm{C}=0), \delta 148.98(\mathrm{C}=\mathrm{N}), \delta 43.69$ $\left(\mathrm{CH}_{2}\right), \delta 12.39\left(\mathrm{CH}_{3}\right), \delta 150.29(\mathrm{~N}-\mathrm{C}), \delta 111.05-134.59(\mathrm{Ar}-\mathrm{C})$; MS (ESI): $\mathrm{m} / \mathrm{z} 412.3(\mathrm{M}+\mathrm{H})^{+}$.

(E)-N'-(4-isopropylbenzlidene)-4-(1Hbenzo[d]imidazol-2-yl) benzohydrazide

Yield 80.3\%; M.P. 280-282 ${ }^{\circ} \mathrm{C}$; FTIR (KBr) 3476 (NH of hydrazide), 3221 (NH OF imidazole), 3053 (CH3), 2870 (=CH2 str.), 1682 (C=0), 1632 ( $\mathrm{NH}$ bend.), 1613 (C=N), 1177 (C-N), 1451-1511 (ring breathing), 1425 (CH2), 1365 (CH3), 824 (p-disubs.), 764-666 (CH bend oop); ${ }^{1} \mathrm{H}-\mathrm{NMR}$ (400 MHz, DMSO) $\delta \mathrm{ppm}: \delta 13.1 \mathrm{ppm}(\mathrm{s}, 1 \mathrm{H}, \mathrm{NH}), \delta 11.93 \mathrm{ppm}(\mathrm{s}, 1 \mathrm{H}$, $\mathrm{CH}=\mathrm{N}), \delta 7.22-8.48(\mathrm{~m}, 13 \mathrm{H}, \mathrm{Ar}-\mathrm{H}), \delta 1.18-1.21\left(\mathrm{~m}, 6 \mathrm{H}, \mathrm{CH}_{3}\right)$, $\delta 2.98(\mathrm{~m}, 1 \mathrm{H}, \mathrm{CH}) ;{ }^{13} \mathrm{C}-\delta 162.46(\mathrm{C}=0), \delta 150.76(\mathrm{C}=\mathrm{N}), \delta$ $33.35(\mathrm{CH}), \delta 23.60\left(\mathrm{CH}_{3}\right), \delta$ 111.51-150.25 (Ar-C); MS (ESI): $\mathrm{m} / \mathrm{z} 383.3(\mathrm{M}+\mathrm{H})^{+}$

(E)-N'-(4-isopropylbenzlidene)-4-(1H-naphtho d]imidazol-2-yl)benzohydrazide

Yield 65.48\%; M.P. $275{ }^{\circ} \mathrm{C}$; FTIR (KBr) 3485 (NH of hydrazide), 3211 (NH of imidazole), 3053 (=CH str.), 2961 (CH3 str.), 1660 ( $\mathrm{C}=0$ ), 1628 ( $\mathrm{C}=\mathrm{N}$ bend.), 1612 (NH bend.), 1173 (C-N str.), 1449-1511 (ring breathing), 1363 (CH3 bend.), 1011-1289 (CH bend. In-plane), 827 (p-disubs. ring),

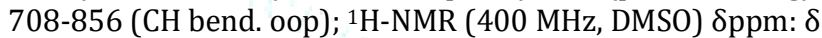
$13.15 \mathrm{ppm}(\mathrm{s}, 1 \mathrm{H}, \mathrm{NH}), \delta 11.97 \mathrm{ppm}(\mathrm{s}, 1 \mathrm{H}, \mathrm{CH}=\mathrm{N}), \delta 7.31-$ $8.49(\mathrm{~m}, 15 \mathrm{H}, \mathrm{Ar}-\mathrm{H}), \delta 1.17-1.21\left(\mathrm{~m}, 6 \mathrm{H}, \mathrm{CH}_{3}\right), \delta 2.87-2.92$ $(\mathrm{m}, 1 \mathrm{H}, \mathrm{CH}) ;{ }^{13} \mathrm{C}-\delta 162.41(\mathrm{C}=0), \delta 154.51(\mathrm{C}=\mathrm{N}), \delta 33.36$ (CH), $\delta 23.60\left(\mathrm{CH}_{3}\right), \delta$ 106.51-154.37 (Ar-C);MS (ESI): $\mathrm{m} / \mathrm{z}$ 433.3(M+H)+

\section{(E)-4-(1H-benzo[d]imidazol-2-yl)-N'-((2-} hydroxynaphthalen-7-yl)methylene) benzohydrazide

Yield 90.9\%; M.P. $308-309{ }^{\circ} \mathrm{C}$; FTIR (KBr) 3253 (NH of hydrazide), 3070 (NH of imidazole), 1693 (C=0), 1623 (C=N), 1595 (NH bend.), 1456-1498 (ring breathing), 1470 (-CH2 bend.), 1324 (C-N str.), 1244 (C-O str.), 1020-1297 (CH bend. In-plane), 814 (p-disubs. ring), 711-940 (CH bend. oop); ${ }^{1} \mathrm{H}-\mathrm{NMR}$ (400 MHz, DMSO) $\delta$ ppm: $\delta 12.82 \mathrm{ppm}(\mathrm{s}, 1 \mathrm{H}$, $\mathrm{NH}), \delta 9.93 \mathrm{ppm}(\mathrm{s}, 1 \mathrm{H}, \mathrm{CH}=\mathrm{N}), \delta$ 7.53-8.41 (m, 10H, Ar-H), $\delta$ 7.2-7.5 (m, 4H, Ar-H), $\delta 12.32(\mathrm{~m}, 1 \mathrm{H}, \mathrm{OH}) ;{ }^{13} \mathrm{C}-\delta 172.01$ $(\mathrm{C}=0), \delta 158.07(\mathrm{C}=\mathrm{N}), \delta 108.5-120.5(\mathrm{Ar}-\mathrm{C}), \delta 161.87(\mathrm{OH})$, $\delta$ 122.52-150.18 (Ar-C); MS (ESI): $\mathrm{m} / \mathrm{z} 407.3(\mathrm{M}+\mathrm{H})^{+}$.

(E)-N'-(3, 5-dimethoxybenzlidene)-4-(1H-benzo[d] imidazol-2-yl) benzohydrazide

Yield 84\%; M.P. $282^{\circ} \mathrm{C}$; FTIR (KBr) 3407 (NH of hydrazide), 3087 (NH of imidazole), $1660(-\mathrm{C}=0), 1616(-\mathrm{C}=\mathrm{N}), 1587$ (NH bend.), 1459-1500 (ring breathing), 1337, 1372 (CH3 bend.), 1305 (C-N str.), 1125-1281 (C-H bend. In-plane), 1113, 1055 (C-O str.), 838 (p-disubs. ring), 855 (p-disubs. ring), 706-891 (C-H bend. oop); ${ }^{1} \mathrm{H}-\mathrm{NMR}$ (400 MHz, DMSO) $\delta p p m: \delta 12.0 \mathrm{ppm}(\mathrm{s}, 1 \mathrm{H}, \mathrm{NH}), \delta 8.4 \mathrm{ppm}(\mathrm{s}, 1 \mathrm{H}, \mathrm{CH}=\mathrm{N}), \delta$ 6.58-8.35 (m, $12 \mathrm{H}, \mathrm{Ar}-\mathrm{H}), \delta 3.79\left(\mathrm{~m}, 6 \mathrm{H}, \mathrm{OCH}_{3}\right) ;{ }^{13} \mathrm{C}-\delta 162.63$ $(\mathrm{C}=0), \delta 160.68(\mathrm{C}=\mathrm{N}), \delta 55.29\left(\mathrm{OCH}_{3}\right), \delta 111.51-150.14(\mathrm{Ar}-$ C); MS (ESI): $\mathrm{m} / \mathrm{z} 401.3(\mathrm{M}+\mathrm{H})^{+}$.

(E)-N'-(2,5-dimethoxybenzlidene)-4-(1H-naphtho[2,3-d] imidazol-2-yl) benzohydrazide

Yield 91.6\%; M.P. $166-168{ }^{\circ} \mathrm{C}$; FTIR (KBr) 3154 (NH of hydrazide), 2827 ( $\mathrm{NH}$ of imidazole), 1652 (-C=0), 14671493 (ring breathing), 1361 (C-N str.), 1220.11, 1199.77 (C0 str.), 1021-1277 (C-H bend. In-plane), 706-894 (C-H bend. oop); ${ }^{1} \mathrm{H}-\mathrm{NMR}(400 \mathrm{MHz}, \mathrm{DMSO}) \delta \mathrm{ppm}: \delta 13.2 \mathrm{ppm}(\mathrm{s}, 1 \mathrm{H}$, $\mathrm{NH}), \delta 12.05 \mathrm{ppm}(\mathrm{s}, 1 \mathrm{H}, \mathrm{CH}=\mathrm{N}), \delta 6.98-8.86(\mathrm{~m}, 14 \mathrm{H}, \mathrm{Ar}-\mathrm{H})$, 
$\delta 3.76-3.82\left(\mathrm{~m}, 6 \mathrm{H}, \mathrm{OCH}_{3}\right) ;{ }^{13} \mathrm{C}-\delta 171.99(\mathrm{C}=0), \delta 162.30$ $(\mathrm{C}=\mathrm{N}), \quad \delta 55.41-56.19\left(\mathrm{OCH}_{3}\right), \quad \delta \quad 109.21-154.37$ (Ar-C);MS (ESI): $\mathrm{m} / \mathrm{z}$ 451.3(M+H)+.

(E)-N'-(3, 4, 5-trimethoxybenzlidene)-4-(1H-naphtho [2, 3-d] imidazol-2-yl) benzohydrazide

Yield 78\%; M.P. $167{ }^{\circ} \mathrm{C}$; FTIR (KBr) 3503.31 (NH of hydrazide), 2947 (NH of Imidazole), 1707 (-C=0), 1614 ($\mathrm{C}=\mathrm{N}$ ), 1587 (NH bend.), 1461- 1551 (ring breathing), 1327 (C-N str.), 1188-1276 (C-H bend. in-plane), 1125, 1108, 1125 (-C-O str.), 827 (p-disubs. ring), 710-855 (C-H bend. oop); ${ }^{1} \mathrm{H}-\mathrm{NMR}(400 \mathrm{MHz}, \mathrm{DMSO}) \delta \mathrm{ppm}: \delta 13.17 \mathrm{ppm}(\mathrm{s}, 1 \mathrm{H}, \mathrm{NH}), \delta$ $9.89 \mathrm{ppm}(\mathrm{s}, 1 \mathrm{H}, \mathrm{CH}=\mathrm{N}), \delta$ 7.24-8.44 (m, 13H, Ar-H), $\delta 3.45-$ $3.90\left(\mathrm{~m}, 9 \mathrm{H}, \mathrm{OCH}_{3}\right) ;{ }^{13} \mathrm{C}-\delta 165.70(\mathrm{C}=0), \delta 154.31(\mathrm{C}=\mathrm{N}), \delta$ $52.26\left(\mathrm{OCH}_{3}\right), \delta 106.69-154.07$ (Ar-C);MS (ESI): m/z 481.3( $\mathrm{M}+\mathrm{H})^{+}$.

(E)-N'-(2, 4-dimethoxybenzlidene)-4-(1H-naphtho [2, 3-d] imidazol-2 yl) benzohydrazide

Yield 84.8\%; M.P. 289-291 ${ }^{\circ} \mathrm{C}$; FTIR (KBr) 3491.84 (NH for hydrazide), 3203 (NH of imidazole), 3080 and 3049 (-CH3 str.), 1659 ( $-\mathrm{C}=0), 1626$ ( $\mathrm{C}=\mathrm{N}), 1601$ ( $\mathrm{NH}$ bend.), 1466-1520 (ring breathing),1372 (-CH3 bend.), 1353 and 1311 (C-N str.), 1011-1289 (C-H bend. in-plane), 811 and 855 (pdisubs. ring), 710-786 (C-H bend. oop); ${ }^{1} \mathrm{H}-\mathrm{NMR}$ (400 MHz, DMSO) $\delta$ ppm: $\delta 13.12 \mathrm{ppm}(\mathrm{s}, 1 \mathrm{H}, \mathrm{NH}), \delta 11.84 \mathrm{ppm}(\mathrm{s}, 1 \mathrm{H}$, $\mathrm{CH}=\mathrm{N}), \delta$ 6.63-8.77 $(\mathrm{m}, 12 \mathrm{H}, \mathrm{Ar}-\mathrm{H}), \delta 3.45-3.90(\mathrm{~m}, 6 \mathrm{H}$, $\left.\mathrm{OCH}_{3}\right) ;{ }^{13} \mathrm{C}-\delta 172.03(\mathrm{C}=\mathrm{O}), \delta 162.50(\mathrm{C}=\mathrm{N}), \delta 55.39\left(\mathrm{OCH}_{3}\right), \delta$ 106.39 -159.21 (Ar-C);MS (ESI): $\mathrm{m} / \mathrm{z} 401.3(\mathrm{M}+\mathrm{H})^{+}$.

(E)-N'-(4-(diethylamino) benzlidene)-4-(1H-naphtho [2, 3d] imidazol-2-yl) benzohydrazide

Yield 64.20\%; M.P. 203-205 ${ }^{\circ} \mathrm{C}$; FTIR (KBr) 3230.2 (NH of hydrazide), 3090 (NH of Imidazole), 3023 (CH3 str.), 2968, 2941 and 2840 (CH str.), 1653 (C=0), $1631(\mathrm{C}=\mathrm{N}), 1615$ (NH bend.), 1450-1466 (ring breathing), 1243 (C-O str.), 10131277 (CH bend. In-plane), 815, 839 (p-disubs. ring), 735-893 (CH bend. oop); ${ }^{1} \mathrm{H}-\mathrm{NMR}$ (400 MHz, DMSO) $\delta$ ppm: $\delta 13.06$ ppm (s, $1 \mathrm{H}, \mathrm{NH}), \delta 11.64 \mathrm{ppm}(\mathrm{s}, 1 \mathrm{H}, \mathrm{CH}=\mathrm{N}), \delta 6.58-8.38(\mathrm{~m}$, $14 \mathrm{H}, \mathrm{Ar}-\mathrm{H}), \delta$ 0.96-1.00 (m, 6H, CH $), \delta 3.22-3.37(\mathrm{~m}, 4 \mathrm{H}$, $\left.\mathrm{CH}_{2}\right) ;{ }^{13} \mathrm{C}-\delta 161.98(\mathrm{C}=0), \delta 149.16(\mathrm{C}=\mathrm{N}), \delta 43.67\left(\mathrm{CH}_{2}\right)$, $\delta 12.36\left(\mathrm{CH}_{3}\right), \delta 154.46(\mathrm{~N}-\mathrm{C}), \delta$ 106.77-148.90 (Ar-C);MS (ESI): $\mathrm{m} / \mathrm{z} 462.4(\mathrm{M}+\mathrm{H})^{+}$

(E)-N'-(2-hydroxy-3-ethoxybenzlidene)-4-(1Hnaphtho[2,3-d]imidazol-2-yl) benzohydrazide

Yield 94.41\%, M.P. $200^{\circ} \mathrm{C}$; FTIR (KBr) 3221 (NH of hydrazide), 3063 (NH of Imidazole), 1664(C=0), 1611(C=N), 1555 (NH bend.), 1465 and 1491 (ring breathing), 1433 (C-
O-H bend.), 1357 (C-N str.), 1019-1308 (CH bend. In-plane), 1130 (C-O str.), 838 (p-disubs. ring), 705- 893 (CH bend. oop); ${ }^{1} \mathrm{H}-\mathrm{NMR}$ (400 MHz, DMSO) $\delta \mathrm{ppm:} \delta 10.28 \mathrm{ppm}(\mathrm{s}, 1 \mathrm{H}$, $\mathrm{NH}), \delta 7.53-8.98(\mathrm{~m}, 10 \mathrm{H}, \mathrm{Ar}-\mathrm{H}), \delta 4.0\left(\mathrm{~m}, 4 \mathrm{H}, \mathrm{OCH}_{2}\right), \delta 10.28$ $(\mathrm{m}, 1 \mathrm{H}, \mathrm{OH}), \delta 1.3 \mathrm{ppm}\left(\mathrm{m}, 6 \mathrm{H}, \mathrm{CH}_{3}\right) ;{ }^{13} \mathrm{C}-\delta 192.51(\mathrm{C}=0), \delta$ $166.81(\mathrm{C}=\mathrm{N}), \delta 64.3\left(\mathrm{OCH}_{2}\right), \delta 14.65\left(\mathrm{CH}_{3}\right), \delta 118.34-154.03$ (Ar-C);MS (ESI): m/z 451.3(M+H)+

\section{(E)-N'-(2-hydroxy-3-ethoxybenzlidene)-4-(1H- benzo[d]imidazol-2-yl) benzohydrazide}

Yield 91.44\%; M.P. $272{ }^{\circ} \mathrm{C}$; FTIR (KBr) 3502 (NH of hydrazide), 3053 (NH of imidazole), 2963 (CH3 str.), 2925 (CH str.), 1708 (C=0), $1615(\mathrm{C}=\mathrm{N}), 1455-1468$ (Ring breathing), 1275 (C-O-H bend.), 1071-1249 ( $\mathrm{CH}$ in-plane bend.), 1109 (C-O str.), 1089 (C-N str.), 800-850 (p disubs. ring), 711-780 (CH oop bend.); ${ }^{1} \mathrm{H}-\mathrm{NMR}$ (400 MHz, DMSO) $\delta$ ppm: $\delta 13.12 \mathrm{ppm}(\mathrm{s}, 1 \mathrm{H}, \mathrm{NH}), \delta 12.21 \mathrm{ppm}(\mathrm{s}, 1 \mathrm{H}, \mathrm{CH}=\mathrm{N}), \delta$ 7.14-8.36 (m, 6H, Ar-H), $\delta 4.0\left(\mathrm{~m}, 4 \mathrm{H}, \mathrm{OCH}_{2}\right), \delta 11.08(\mathrm{~m}, 1 \mathrm{H}$, $\mathrm{OH}), \delta 1.3 \mathrm{ppm}\left(\mathrm{m}, 6 \mathrm{H}, \mathrm{CH}_{3}\right) ;{ }^{13} \mathrm{C}-\delta 162.20(\mathrm{C}=0), \delta 150.27$ $(\mathrm{C}=\mathrm{N}), \delta 14.70\left(\mathrm{CH}_{3}\right), \delta 148.87(\mathrm{OH}), 64.13\left(\mathrm{CH}_{2}\right), \delta 115.27-$ 147.58 (Ar-C);MS (ESI): m/z 401.3(M+H)+

\section{Assay for $\alpha$-Glucosidase Inhibitory Activity}

The $\alpha$-glucosidase inhibition activity was carried out at School of Biochemistry, Devi Ahilya Vishwavidyalaya, Indore, M.P. Potassium dihydrogen phosphate (4.35 g) and $3.55 \mathrm{~g}$ of disodium hydrogen phosphate was dissolved in $100 \mathrm{ml}$ distilled water and sufficient water was added to produce $500 \mathrm{ml}$ of phosphate buffer $\mathrm{pH} 6.8,50 \mathrm{mM}$. The substrate (p-Nitrophenyl- $\alpha$-D-glucopyranoside) solution 0.7 $\mathrm{mM}$ was prepared in buffer solution. $0.14 \mathrm{mg}$ of the enzyme $\alpha$-glucosidase. Test compounds $10 \mathrm{mg}, 20 \mathrm{mg}, 30 \mathrm{mg}, 40 \mathrm{mg}$ and $50 \mathrm{mg}$ were dissolved in the DMSO and further dilutions were made with distilled water. Enzyme $(20 \mu \mathrm{l}), 20 \mu \mathrm{l}$ of test samples and $135 \mu \mathrm{l}$ of the buffer solution was added to the 96-well plates. The solution was pre-incubated for 15 minutes at $37{ }^{\circ} \mathrm{C}$. Instead of test samples $20 \mu \mathrm{l}$ of DMSO is added in case of control (Zawawi et al. 2016). Substrate (25) was added and incubated for $30 \mathrm{~min}$. After that the shaking of the 96-well plate is done for $15 \mathrm{~s}$ and absorbance was taken at $405 \mathrm{~nm}$. All experiments were triplicated and the results were expressed as the percentage inhibition of three determinations. The enzyme inhibitory rates of samples were calculated as follows:

Percentage inhibition $=[$ (absorbance of control - absorbance of the test sample)/ absorbance of control] $\times 100$

\section{RESULT AND DISCUSSION}

Chemistry

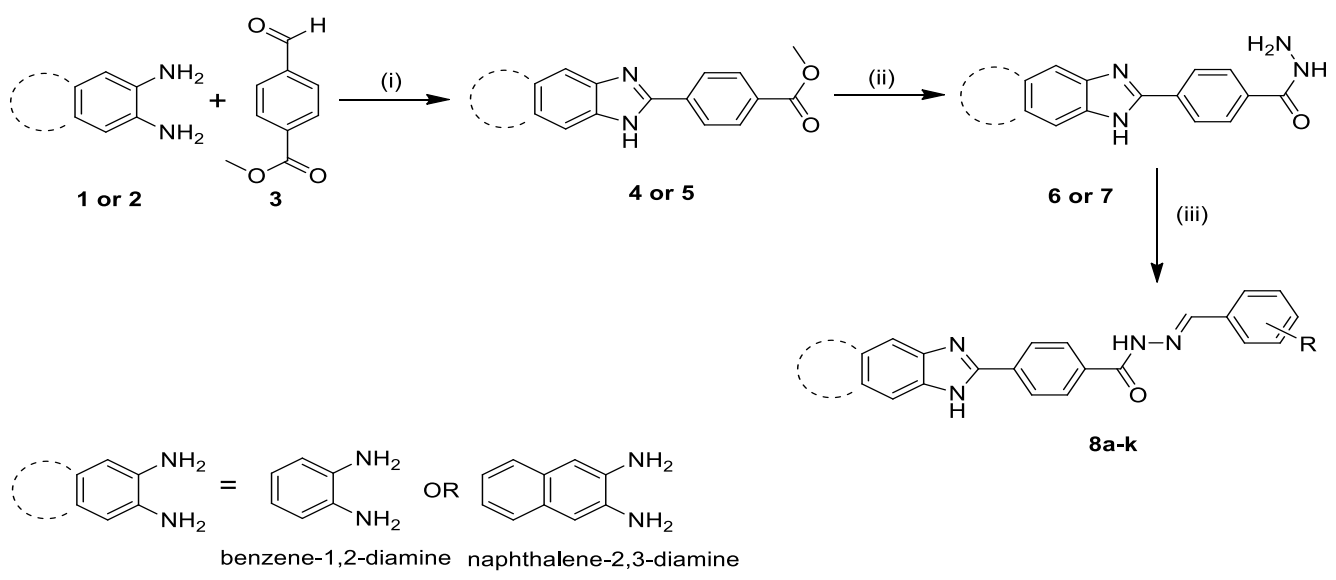

Figure 1: Reaction conditions for synthesis of substituted benzimidazoles: (i) 30\% hydrogen peroxide or ceric ammonium nitrate; (ii) hydrazine hydrate; (iii) substituted benzaldehyde. 
The designed 11 benzimidazoles having different substitutions were synthesized from good to excellent yields. First intermediate (IM 1) was formed in oxidation reaction using ceric ammonium nitrate, the carbonyl carbon of the aldehyde was attacked by the nitrogen atom of either ophenylenediamine or 2, 3-diamino naphthalene followed by the removal of the water molecule, ring cyclization and oxidized in presence of ceric ammonium nitrate. In the intermediate so formed nucleophilic addition of the hydrazine moiety took place in the second step after the removal of methanol as good leaving group. This intermediate (IM 2) undergoes the Mannich reaction to form the final product in good yield as shown in Scheme 1. All these compounds (1-11) were characterized by spectroscopic methods (IR, NMR, and MS).

\section{Enzyme Inhibitory Studies}

The novel synthesized compounds were evaluated for the $\alpha$ glucosidase inhibitory activity using commercially available $\alpha$-glucosidase inhibitor acarbose as positive control. Compounds 1, 3, 4, 6, 7, 9, 10 and 11 showed significant activity as compared with the standard drug acarbose. From these tested compounds, three compounds were found to be most active. Compound 9, 10 and 3 inhibited the enzyme $\alpha$ glucosidase by $90.84 \%, 78.67 \%$ and $89.96 \%$ respectively at the minimum dose concentration that is $10 \mu \mathrm{g} / \mathrm{ml}$. The standard drug acarbose inhibited $55.95 \%$ of the enzyme $\alpha$ glucosidase at the same concentration.
The most active analog among the series is 9 which was having benzyl group at $R_{1}$ and 4-diethyl amino group at $R_{2}$. The second most active compound is 10 which was having benzyl group at the $\mathrm{R}_{1}$ and 2-hydroxy-3-ethoxy at $\mathrm{R}_{2}$. Similarly, the third potent analog was 3 which was having benzyl group at the R1and 4-isopropyl group at $\mathrm{R}_{2}$. All these substituents resulted in hydrogen bonding with the crucial amino-acids having significant role in the activity.

Based on the percentage inhibition results of these compounds the $\mathrm{IC}_{90}$ values were calculated by plotting the graph of the concentration versus the percentage inhibition of the enzymatic activity extrapolating the $90 \%$ inhibition to the concentration. It was found that the $\mathrm{IC}_{90}$ value of the standard drug acarbose was found to be $290.55 \pm 0.081$ $\mu \mathrm{g} / \mathrm{ml}$, and that of 9,3 and 10 it was found at $6.02 \pm 1.10$ $\mu \mathrm{g} / \mathrm{ml}, 12.94 \pm 1.41 \mu \mathrm{g} / \mathrm{ml}$ and $33.25 \pm 1.20 \mu \mathrm{g} / \mathrm{ml}$.

The $\mathrm{IC}_{90}$ value of the synthesized compounds were found to be lower than the standard drug acarbose means they will have even less $\mathrm{IC}_{50}$ value concluding they could have a considerable inhibitory activity against the standard drug acarbose.

On the basis of the in vitro activity of the $\alpha$-glucosidase inhibition it was found that nearly all compounds were more potent than standard drug acarbose so further these compounds can be proceeded for the toxicity studies and pharmacodynamics studies.

Table 1. $\alpha$-glucosidase inhibitory activity of benzohydrazide benzimidazoles derivatives (1-11).

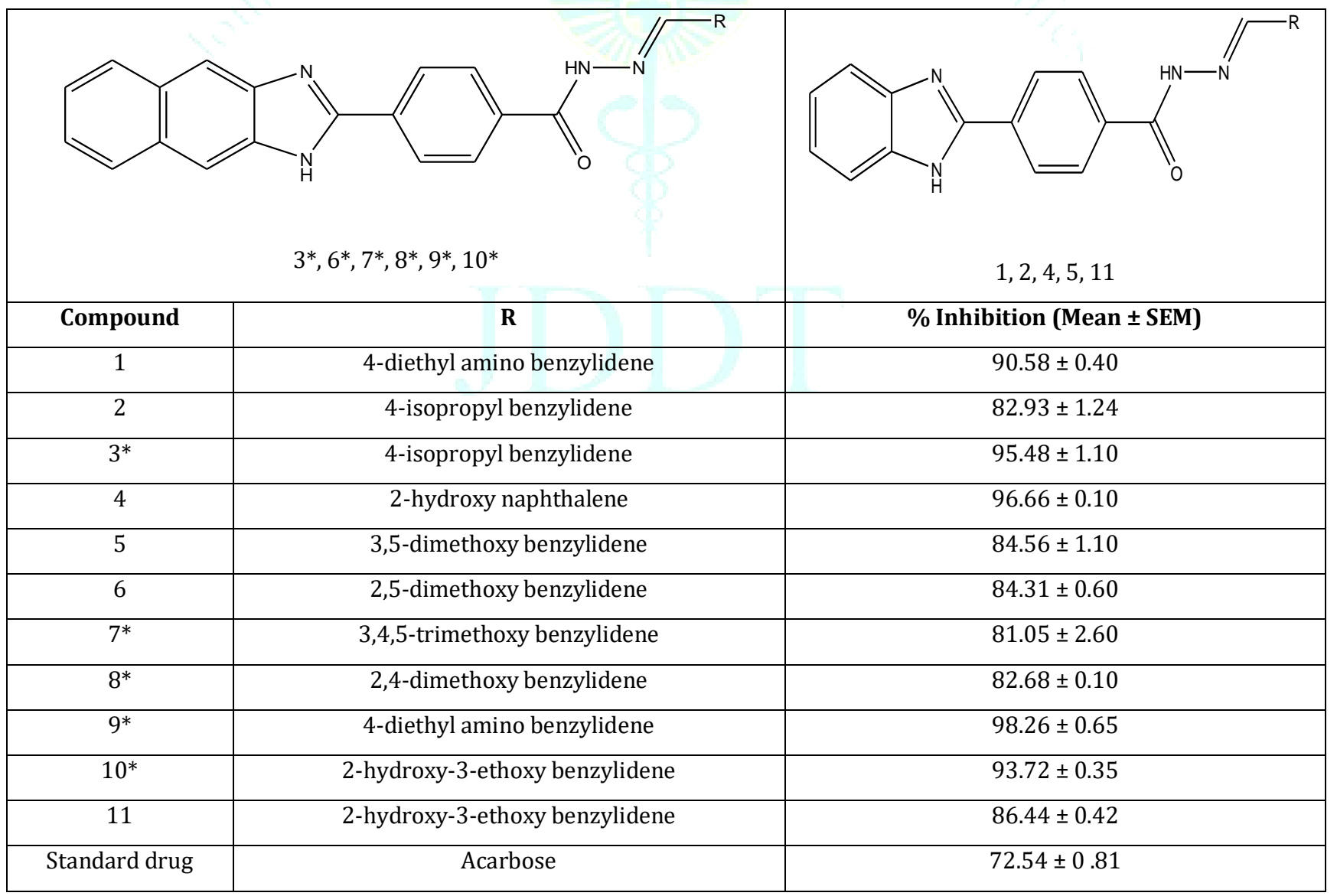




\section{Molecular Docking}

In compound 9, the tertiary amino group was one of the strong electron donating and also contributed in formation of hydrogen bond with amino acid Glu 332 which was found to be very important for the activity.
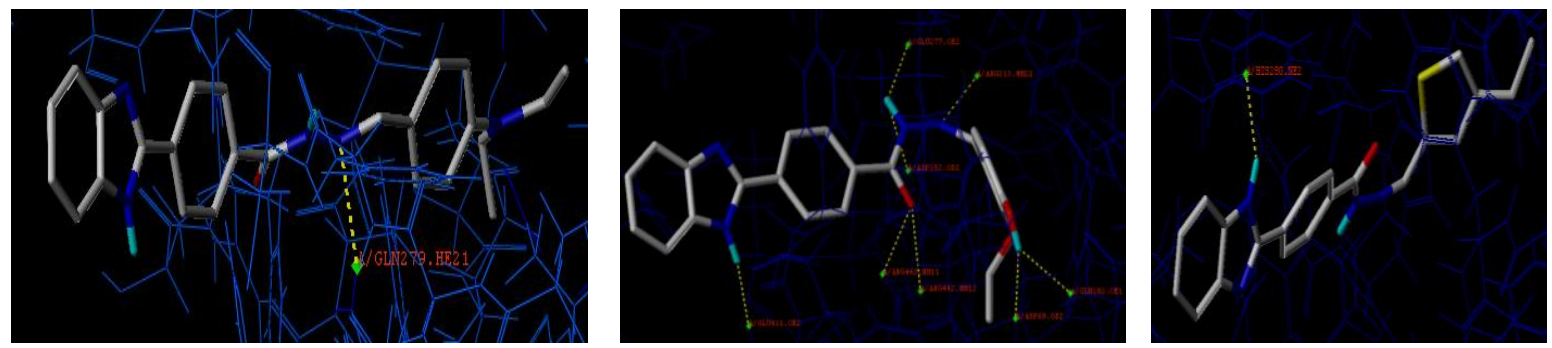

Figure 2. Docking pose of compound 9, 10 and 3 in the active site.

The second most active compound 10 had a benzyl group at $\mathrm{R}_{1}$ and 2-hydroxy-3-ethoxy at $\mathrm{R}_{2}$. The hydroxyl and alkoxy groups were individually among the strong electron donating groups and also contribute to the important interactions with the active site of enzyme. Arg 335 was found to be critical for the binding of the substrate at the active site of enzyme and Asp 519 forms hydrogen bond at the distance between $2.7-2.5 \mathrm{~A}^{\circ}$ with the enzyme. Compound 3 had a benzyl group at $\mathrm{R}_{1}$ and 4-isopropyl at $\mathrm{R}_{2}$. 4-isopropyl was considered to be weak electron donating group but formed hydrogen bond with the oxygen molecule of the amino acid residue Asp 69. It was observed that the marketed $\alpha$-glucosidase inhibitors were bulky molecules. The cavity of the active site should be large that might be the reason for the increased activity of the naphtho-imidazoles than benzimidazoles. It can be concluded that the hypotheses of the SAR made from computational studies was found to be correct as per the in vitro activity results. A bulky group should be placed at $R_{1}$ and stronger electron donating group needs to be substituted at $R_{2}$ for enhanced $\alpha$ glucosidase inhibitory activity.

Table 11: Docking score of designed compounds.

\begin{tabular}{|c|c|c|c|c|c|c|c|c|c|}
\hline S.N. & $\mathbf{R}$ & $\begin{array}{l}\text { Total } \\
\text { score }\end{array}$ & Crash & Polar & D score & $\begin{array}{l}\text { PMF } \\
\text { score }\end{array}$ & G score & $\begin{array}{l}\text { ChemSco } \\
\text { re }\end{array}$ & $\begin{array}{l}\text { CS } \\
\text { score }\end{array}$ \\
\hline 1. & $3,4-\mathrm{OC}_{2} \mathrm{H}_{5}$ & 3.81 & -6.24 & 2.44 & -193.62 & -152.33 & -241.75 & -39.03 & 1 \\
\hline 2. & 3-ethoxy-4-hydroxy & 4.40 & -2.45 & 4.24 & -146.21 & -158.65 & -209.26 & -33.30 & 1 \\
\hline 3. & 4-dimethyl amino & 2.77 & -1.28 & 0.93 & -134.45 & -61.370 & -188.77 & -30.48 & 1 \\
\hline 4. & 4-diethyl amino & 5.31 & -2.59 & 0.01 & -183.44 & -110.25 & -260.77 & 32.54 & 2 \\
\hline 5. & 4-ethyl & 4.20 & -2.10 & 0.70 & -143.07 & -114.35 & -255.61 & -28.42 & 0 \\
\hline 6. & 2,5-dimethoxy & 5.53 & -2.34 & 1.54 & -172.44 & -159.95 & -176.77 & -31.97 & 3 \\
\hline 7. & 2,4-dimethoxy & 4.63 & -5.02 & 1.64 & -199.71 & -152.83 & -270.99 & -39.55 & 1 \\
\hline 8. & 2-ethoxy-4-hydroxy & 5.53 & -4.12 & 2.71 & -196.27 & -153.80 & -237.78 & -43.27 & 1 \\
\hline 9. & 2-hydroxy-3-methoxy & 5.10 & -5.26 & 4.19 & -191.03 & -160.26 & -295.48 & -42.86 & 0 \\
\hline 10. & 3-ethoxy-2-hydroxy & 5.03 & -4.32 & 1.22 & -207.77 & -160.03 & -315.82 & -35.14 & 0 \\
\hline 11. & 3,4,5- trimethoxy & 5.47 & -2.57 & 2.01 & -190.93 & -77.444 & -247.700 & -34.3814 & 0 \\
\hline 12. & 4-isopropyl & 5.78 & -2.27 & 0.001 & -165.30 & -103.38 & -256.098 & -31.4411 & 1 \\
\hline 13. & 4-acetamido & 3.89 & -1.53 & 1.49 & -143.93 & -107.27 & -196.830 & -27.3129 & 2 \\
\hline 14. & 2,6- dimethoxy & 2.41 & -2.80 & 0.0001 & -180.18 & -135.46 & -267.256 & -33.3888 & 1 \\
\hline 15. & 4-hydroxy-2-methoxy & 4.51 & -5.71 & 3.2449 & -193.29 & -150.07 & -271.467 & -42.2919 & 0 \\
\hline 16. & 2-hydroxy-6-methoxy & 4.67 & -4.21 & 1.5344 & -202.13 & -140.97 & -288.026 & -34.6364 & 1 \\
\hline 17. & 2,3-dimethoxy & 4.99 & -1.79 & 1.08 & -158.54 & -119.97 & -199.31 & -30.44 & 0 \\
\hline 18. & 2,3,4- trimethoxy & 3.05 & -6.25 & 1.46 & -208.62 & -176.35 & -292.61 & -35.25 & 3 \\
\hline 19. & 3,5-dimethoxy & 6.81 & -5.34 & -2.73 & -213.70 & $\begin{array}{l}-169.8 \\
-16.8\end{array}$ & -299.4 & -44.16 & 1 \\
\hline 20. & 2,4,6- trimethoxy & 3.95 & -5.32 & 6.65 & -175.80 & -182.48 & -292.39 & -43.23 & 3 \\
\hline
\end{tabular}




\begin{tabular}{|c|c|c|c|c|c|c|c|c|c|}
\hline 21. & 1-methoxy naphthalene & 2.30 & -4.59 & 1.09 & -163.26 & -84.639 & -227.51 & -36.62 & 1 \\
\hline 22. & 2-methoxy naphthalene & 2.93 & -4.06 & 0.02 & -235.77 & -56.110 & -301.99 & -59.72 & 2 \\
\hline 23. & 2-ethoxy naphthalene & 2.40 & -4.15 & 1.79 & -184.36 & -85.596 & -269.44 & -43.11 & 2 \\
\hline 24. & 2-hydroxy naphthalene & 4.48 & -3.87 & 1.21 & -208.84 & -6.0921 & -327.25 & -53.92 & 1 \\
\hline 25. & 1, 4-dimethoxy naphthalene & 3.03 & -4.20 & 0.91 & -197.77 & -116.78 & -253.07 & -40.56 & 2 \\
\hline 26. & 1-indol-2-yl & 3.82 & -7.31 & 4.04 & -185.33 & -138.15 & -275.25 & -45.22 & 2 \\
\hline 27. & 4-ethylthiophen-2-yl & 4.41 & -3.77 & 1.87 & -181.85 & -8.7379 & -254.40 & -44.54 & 1 \\
\hline 28. & Quinolin-3-yl & 4.87 & -1.75 & 0.04 & -165.85 & -114.18 & -240.56 & -31.44 & 2 \\
\hline 29. & 2-hydroxy-4-methoxy & 4.87 & -2.36 & 3.59 & -169.39 & -181.02 & -227.96 & -35.82 & 0 \\
\hline 30. & 3,4,5- trimethoxy & 3.22 & -3.00 & 0.03 & -174.48 & -106.45 & -212.32 & -25.58 & 0 \\
\hline $31 .^{*}$ & $3,4-\mathrm{OC}_{2} \mathrm{H}_{5}$ & 5.97 & -3.01 & 0.06 & -189.57 & -146.58 & -247.28 & -29.09 & 3 \\
\hline 32 . $^{*}$ & 3-ethoxy-4-hydroxy & 4.18 & -5.25 & 3.85 & -173.60 & -165.93 & -243.86 & -37.08 & 1 \\
\hline 33.* & 4-dimethyl amino & 5.25 & -3.37 & 0 & -152.04 & -116.51 & -270.76 & -31.62 & 2 \\
\hline $34 .^{*}$ & 4-diethyl amino & 6.69 & -2.43 & 0.19 & -178.50 & -115.03 & -252.62 & -29.47 & 4 \\
\hline $35 .^{*}$ & 4-ethyl & 4.87 & -0.82 & 0.28 & -143.55 & -121.10 & -219.30 & -30.15 & 0 \\
\hline $36 .^{*}$ & 2,5-dimethoxy & 4.64 & -3.74 & 0.92 & -179.33 & -147.07 & -200.01 & -29.57 & 3 \\
\hline 37.* & 2,4-dimethoxy & 5.34 & -4.03 & 2.47 & -186.16 & -153.46 & -219.65 & -37.37 & 3 \\
\hline 38.* & 2-ethoxy-4-hydroxy & 4.76 & -5.64 & 4.46 & -186.19 & -173.36 & -307.90 & -40.80 & 2 \\
\hline 39.* & 2-hydroxy-3-methoxy & 5.07 & -2.91 & 1.93 & -176.96 & -160.67 & -243.93 & -33.93 & 0 \\
\hline 40.* & 3-ethoxy-2-hydroxy & 4.47 & -4.52 & 1.18 & -191.29 & -156.10 & -304.55 & -30.38 & 2 \\
\hline 41.* & 3,4,5- trimethoxy & 5.15 & -4.94 & 3.13 & -181.05 & -95.176 & -276.14 & -40.44 & 2 \\
\hline 42.* & 4-isopropyl & 5.88 & -1.60 & 0.01 & -162.37 & -99.421 & -268.22 & -30.47 & 2 \\
\hline 43.* & 4-acetamido & 3.86 & -1.64 & 0.089 & -156.27 & -125.77 & -229.04 & -28.04 & 4 \\
\hline 44. ${ }^{*}$ & 2,5- dimethoxy & 6.08 & -1.13 & 1.24 & -147.49 & -136.61 & -174.16 & -32.08 & 4 \\
\hline 45. $*$ & 4-hydroxy-2-methoxy & 5.98 & -2.76 & 1.42 & -175.23 & -157.46 & -274.95 & -31.85 & 1 \\
\hline 46. ${ }^{*}$ & 2-hydroxy-6-methoxy & 5.45 & -3.47 & 3.89 & -179.01 & -180.18 & -225.42 & -39.15 & 4 \\
\hline 47.* & 2,3-dimethoxy & 6.43 & -1.16 & 1.85 & -150.56 & -56.386 & -203.44 & -30.82 & 3 \\
\hline 48.* & 2,3,4- trimethoxy & 4.44 & -2.06 & 1.14 & -162.98 & -140.08 & -191.51 & -33.43 & 5 \\
\hline 49.* & 3,5-dimethoxy & 5.67 & -1.42 & 0.24 & -150.44 & -125.93 & -192.15 & -29.73 & 0 \\
\hline 50.* & 2,4,6- trimethoxy & 5.88 & -2.55 & 3.18 & -168.55 & -191.29 & -227.57 & -32.03 & 1 \\
\hline 51.* & 1-methoxy naphthalene & 4.49 & -5.67 & 1.43 & -175.35 & -70.719 & -251.55 & -37.44 & 2 \\
\hline 52.* & 2-methoxy naphthalene & 5.60 & -1.67 & 0.33 & -161.26 & -115.30 & -252.93 & -31.18 & 0 \\
\hline 53.* & 2-ethoxy naphthalene & 4.95 & -3.38 & 1.17 & -180.89 & -114.44 & -276.61 & -38.52 & 4 \\
\hline 54.* & 2-hydroxy naphthalene & 5.70 & -1.73 & 2.10 & -160.00 & -131.73 & -243.35 & -39.25 & 4 \\
\hline 55.* & 1,4-dimethoxy naphthalene & 5.36 & -2.59 & 2.82 & -167.87 & -139.38 & -217.17 & -38.41 & 2 \\
\hline 56.* & 1-indol-2-yl & 6.65 & -1.84 & 0.02 & -163.33 & -119.67 & -263.51 & -30.38 & 1 \\
\hline 57.* & 4-ethylthiophen-2-yl & 3.20 & -4.36 & 1.11 & -152.52 & -119.87 & -255.72 & -31.19 & 1 \\
\hline 58. $*$ & Quinolin-3-yl & 5.58 & -1.52 & 2.07 & -160.56 & -134.22 & -256.59 & -32.76 & 2 \\
\hline 59.* & 2-hydroxy-4-methoxy & 5.29 & -2.76 & 3.74 & -160.00 & -175.18 & -193.79 & -33.74 & 2 \\
\hline 60.* & 3,4,5- trimethoxy & 3.83 & -2.72 & 0.013 & -172.81 & -137.03 & -232.94 & -26.83 & 0 \\
\hline
\end{tabular}




\section{CONCLUSION}

Eleven benzimidazoles derivatives had been synthesized and evaluated for their $\alpha$-glucosidase inhibitory activities. Based on results obtained from docking and biological evaluation, benzyl group substitution on benzimidazole and electron donating groups like diethyl amino, hydroxyl played an important role in this activity as they were found to be five to eight folds more active as compared to standard drug Acarbose. Compound 9, 10 and 3 bonding with significant amino acids LEU 520, ARG 335 and ASP 69 which were located at the entrance of active site pocket, and if they don't move, the substrate cannot bind at the active site. It can further be concluded from the results that the good inhibitory activity of the compounds may be due to bulky substitution of benzimidazole ring and existence of electron donating group on $\mathrm{R}$.

\section{REFERENCES}

1. Global report on diabetes. WHO, Geneva, 2016.

2. Mathers CD, Loncar D. Projections of global mortality and burden of diseases from 2002 to 2030. Plos Med, 2006; 3(11):442.

3. Alberti K, Zimmet Z. Definition, diagnosis and classification of diabetes mellitus and its complications: Report of a WHO Consultation. 1999; 1:125.

4. Kalra S. Alpha glucosidase inhibitors. J. Pak Med. Assoc. 2014; 64(4):474-476.

5. Hanefeld M, Schaper F. The role of Alpha-Glucosidase Inhibitors (Acarbose). Pharmacotherapy of Diabetes: New Developments. Diabetes: Endocrinology. US Springer, 2007; 143-52.

6.A.N. Aziz, M. Taha, N.H. Ismail, E.H. Anouar, S. Yousuf, W. Jamil, K. A wang, N. Ahmat, K.M. Khan, S.M. Kashif, Synthesis, crystal structure, DFT studies and evaluation of the antioxidant activity of 3,4-dimethoxybenzenamine schiff bases, Molecules, 2014 19:8414-8433

7.S. Imran, M. Taha, N.H. Ismail, K.M. Khan, F. Naz, M. Hussain, S. Tau seef, Synthesis of novel bisindolylmethane schiff bases and their antibacterial activity Molecules, 2014; 19:11722-11740

8.W. Jamil, S. Perveen, S.A.A. Shah, M. Taha, N.H. Ismail, S. Perveen, N. Ambreen, K.M. Khan, M.I. Choudhary, Phenoxyacetohydrazide schiff bases: $\beta$-glucuronidase inhibitors, Molecules, 2014; 19:8788-8802

9. Jamil, W., Solangi, S., Ali, M., Khan, K.M., Taha, M., Khuhawar, M.Y., 2015 Syntheses, Characterization, In Vitro Antiglycation and DPPH Radical Scavenging Activities of Isatin Salicylhydrazidehydrazone and its Mn (II), Co (II), Ni (II), Cu (II), and $\mathrm{Zn}$ (II) Metal Complexes. Arabian J. Chem. (http://dx.doi.org/10.1016/j.arabjc.2015.02.015) (in press).

10.K.M. Khan, M. Taha, F. Naz, S. Siddiqui, S. Ali, F. Rahim, S. Perveen, M.I. ChoudharyAcylhydrazide Schiff bases: DPPH radical and superoxide anion scavengers, Med. Chem., 2012; 8:705-710

11.K.M. Khan, M. Taha, F. Rahim, M.I. Fakhri, S. Rasheed, F. Rahim, W. Jamil, M. Khan, A. Karim, S. Perveen, M.I. choudharyAcylhydrazi de schiff bases: synthesis and antiglycation activity, J. Chem. Soc. Pak., 2013; 35:930-938

12.K.M. Khan, F. Rahim, N. Ambreen, M. Taha, M. Khan., H. Jahan, Naj eebullah, A. Shaikh, S. Iqbal, S. Perveen, M.I. Choudhary, Synthesis of benzophenonehydrazone Schiff bases and their in vitro antiglycating activities, Med. Chem., 2013; 9:588-595

13.K.M. Khan, M. Irfan, M. Ashraf, M. Taha, S.M. Saad, S. Perveen, M.I. Choudhary, Synthesis of phenyl thiazole hydrazones and their activity against glycation of proteins, Med. Chem. Res., 2015 24:3077-3085

14.M. Taha, N.H. Ismail, M. Ali, K.M. Khan, W. Jamil, S.M. Kashif, M. As raf, Synthesis of indole-2-hydrazones in search of potential leishmanicidal agents, Med. Chem. Res., 2014; 23:5282-5293

15.M. Taha, N.H. Ismail, A. Khan, A.A.S. Syed, A. Anwar, S.A. Halim, M. Q. Fatmi, S. Imran, F. Rahim, K.M. Khan, Synthesis of novel derivatives of oxindole, their urease inhibition and molecular docking studies, Bioorg. Med. Chem. Lett., 2015; 25:3285-3289
16.M. Taha, N.H. Ismail, M.S. Baharudin, S. Lalani, S. Mehboob, K.M. K han, S. yousuf, S. Siddiqui, F. Rahim, M.I. Choudhary, Synthesis crystal structure of 2-methoxybenzoylhydrazones and evaluation of their a-glucosidase and urease inhibition potential Med. Chem. Res., 2015; 24:1310-1324

17.

M. Taha, N.H. Ismail, S. Imran, M.Q.B. Rokei, S.M. Saad, K.M. Khan Synthesis of new oxadiazole derivatives as $\alpha$-glucosidase inhibitors, Bioorg. Med. Chem., 2015; 23:4155-4162

18. Kohno T, Ohtaka H, Tsukamoto G, Yoshino K: Synthesis and antiinflammatory activity of some 2- (substituted-pyridinyl) benzimidazoles. Journal of Medicinal Chemistry 1980, 23:734738.

19. Bhise UN, Kumar SBV, Ramanatham V, Vaidya SD: Synthesis, antibacterial, anti-asthmatic and antidiabetic activities of novel $\mathrm{N}$-substituted benzimidazoles. European Journal of Medicinal Chemistry 2008, 43(5):986-995.

20. Francisco AC, Gabriel NV, Hermenegilda MD: Design, microwaveassisted synthesis and spasmolytic activity of 2-(alkyloxyaryl)$1 \mathrm{H}$-benzimidazole derivatives as constrained stilbene bioisosteres. Bioorganic and Medicinal Chemistry Letters 2006, 16(16):4169-4173.

21. Pashinski VG, Romanova TV, Mukhina NA, Shkrabova LV: Diuretic activity of benzimidazole urea derivatives. Farmakol Toksikol 1978, 41(2):196-9.

22. Durmaz R, Gunal S, Kucukbay H: Synthesis, antibacterial and antifungal activities of electron-rich olefins derived benzimidazole compounds. Science Direct: II Farmaco 2003, 58:431-437.

23. Solominova PS, Pilyugin VS, Pyurin AA: Targated search for new anthelmentic among 5 (6- Aminophenylthio (oxy)-2-amino benzimidazole derivatives. Journal of Pharmaceutical Chemistry 2004, 38:425-430.

24. Gardiner JM, Loyns CR, Burke A, Khan A: Synthesis and HIV -1 inhibition of novel benzimidazole derivatives. Bioorganic and Medicinal Chemistry Letters 1995, 5(12):1251-1254.

25. Bariwal JB, Shah AK, Kathiravan MK, Somani RS, Jagtap JR: Synthesis and antiulcer activity of novel pyrimidylthiomethyl and Pyrimidylsulfinylmethyl benzimidazoles as potential reversible proton pump inhibitors. Indian Journal of Pharmaceutical Education and Research 2008, 42(3):225-231.

26. Durmaz R, Gunal S, Kucukbay H: Synthesis, antibacterial and antifungal activities of electron-rich olefins derived benzimidazole compounds. Science Direct: II Farmaco 2003, 58:431-437.

27. Chimrri A, Sarro AD, Sarro GD, Giho G, Zappala M: Synthesis and anticonvulsant properties of 2, 3, 3a-4-tetrahydro-1-H pyrrolo (1,2-a) benzimidazol-1-one derivatives. Science Direct: II Farmaco 2001, 56(11):821-826.

28. Zawawi et al. Benzimidazole derivatives as new $\alpha$-glucosidase inhibitors and in silico studies. Bioorganic Chemistry J. 2016; 64: 29-36.

29. Taha M. Synthesis crystal structure of 2methoxybenzoylhydrazones and evaluation of their $\alpha$ glucosidase and urease inhibition potential. Medicinal chemistry research J. 2015, 24; 3:1310-1324.

30. Taha M. Synthesis of novel derivatives of 4-methylbenzimidazole and evaluation of their biological activities. European Journal of Medicinal Chemistry. 2014; 84:731-738.

31. Panda SS. Synthesis of 2-arylbenzimidazoles in water. Taylor and Francis J. 2011; 729-735.DOI: 10.1080/00397911003642682.

32. Taha M. Antiglycation and antioxidant potential of novel imidazo [4, 5-b] pyridine benzohydrazones. Arabian journal of chemistry. 2015; 1878-5352. http://dx.doi.org/10.1016/j.arabjc.2015.08.004

33. Rostamizadeh $\mathrm{S}$ et al. Very fast and efficient synthesis of some novel substituted 2-arylbenzimidazoles in water using ZrOCl2.nH2O on montmorillonite K10 as catalyst. Monatsh Chem Springer. 2009; 140:547-552.

34. Kiumars Bahrami. Mild and highly efficient method for the synthesis of 2-Arylbenzimidazoles and 2-Arylbenzothiazoles. JOC. 2008; 73:6835-6837. 